\title{
Media Relations as a Method to Build Private Universities Image (A Case Study in Universitas Tarumanagara)
}

\author{
Alvin Putra Winata ${ }^{1}$ Riris Loisa ${ }^{1 *}$ \\ ${ }^{1}$ Faculty of Communication, Universitas Tarumanagara, West Jakarta, Jakarta 11440, Indonesia \\ "Corresponding author: ririsl@fikom.untar.ac.id
}

\begin{abstract}
Media relations can be used to form an institutional image, including private universities. A good image is an important thing for an institution, such as private universities. As one of the best private universities in Indonesia, Universitas Tarumanagara is one of the private universities that executes media relations through Universitas Tarumanagara Office of Public Relations. The main problem in this research is how media relations form the image of private universities. This research used public relations theory, school (university) public relations theory, media relations theory, and image theory. This research focus is Universitas Tarumanagara Office of Public Relations. This research was conducted with a qualitative approach with a case study method. Data was collected through in-depth interviews and observations. Data processing and analysis were conducted with the coding method. Based on the research, it is found that media relations activities form the image of Universitas Tarumanagara through numerous positive news. Positive news in media could emerge through the success of the Universitas Tarumanagara Office of Public Relations in establishing relationships with media. Not only formal relationships such as news coverage, but also informal relationships such as socializing and mingling with media personnel after events, or conducting events that could bring the relationships with media closer, such as media gathering and inviting as speakers to events. The positive news is evidence of Universitas Tarumanagara's existence and achievements. Through positive news, the public could find out the achievements and qualities that Universitas Tarumanagara owns. Also, the image that is expected by Universitas Tarumanagara will be reflected through that news. This will increase the reputation and public trust in Universitas Tarumanagara, which then will have a role in Universitas Tarumanagara's sustainability.
\end{abstract}

Keywords: public relations, media relations, private universities

\section{INTRODUCTION}

In this digital era, information is readily accessible rapidly throughout the world. The public's necessity for information is growing rapidly. This situation becomes a push for an institution to increase its publications in the media. Therefore, the public could be aware of the institution's achievements. Without publications in media, achievements and information sent out by an institution will not be delivered to the public effectively.

Publications in media could affect the forming of an institution's image. Without publications, an institution will be less known in society. A good institutional image will not be formed in society, regardless of the goods the institution has done.

Image is perceptions, impressions, sensations, and overviews that the public has toward an object. Public relations division in an institution is responsible to form the image of the institution. Public relations is responsible to construct communications between an institution and its public [1].

Public relations' role is also needed in the fields of education, primarily in universities. Universities, although are not focused in profit-making, still need to have public relations managements such as those found in corporates. Educational institutions could bear the same, or even more tasks, functions, and duties as found in corporates.

One of the activities performed by universities' public relations divisions is media relations. Frank Jefkins said that media relations is an effort to publish and broadcast messages or information to the public of an institution optimally, in order to create awareness and understanding among the public [2].

Media relations is also performed in Universitas Tarumanagara by the Office of Public Relations. As one of the best universities in Indonesia, Universitas Tarumanagara consistently creates publications in various media as an effort to be more well-known by the public. 
Currently, Universitas Tarumanagara Office of Public Relations consistently publishes publications regarding achievements and events, while also organises various events.

Unfortunately, there are not many universities in Indonesia that are aware of this. Nasution (in Setyanto \& Anggarina, 2015) said that Indonesian universities public relations are less compared to those in other countries, or to corporates public relations. Public relations in universities usually only tasked for event documentations, collecting news, and publishing news to the media [1].

Universities public relations role in Indonesia are still considered not significant and serve only as complements. Universities public relations rarely involved in decision making and information gathering, making them less optimal [1].

Whereas, university public relations can be a key role in forming the image and reputations of a university in society if functioned optimally. Complemented with good media relations, this activity could produce a long-term advantage to a university. Media relations could result in positive news which in turn will make the public know the achievements of an institution, forming the image and reputations in society.

Universities public relations are not supposed to be focused on profit-making. Nevertheless, in this era, universities, especially private universities, are required to act and think like corporates. Private universities public relations need to perform activities that usually performed in corporates to be able to withstand the increasing competition among private universities.

The main problem in this research is how media relations form the image of private universities. The scope of this research is Universitas Tarumanagara Office of Public Relations. Universitas Tarumanagara is chosen to be the object of this research as it is considered as the best among other private universities. In November 2019, Universitas Tarumanagara was awarded "Private University with the Best and the Most Productive Office of Public Relations" by the Institute of Higher Education Service 3 (LLDIKTI 3), Ministry of Education and Culture of the Republic of Indonesia. The aim of this research is to find out the role of media relations in forming the image of private universities.

\section{METHODS}

This research was conducted with a qualitative approach. Qualitative researches are researches that often used to study the social phenomenon. Different to quantitative researches that depend on numbers, the results of qualitative researches are not based on statistics. Qualitative researches depend on the analysis of gathered data, which then explained based on series of analysis [3]. The research method that used in this research was a case study. Yin [4] said that a case study is aimed to explain how and why a case is happening, not just explaining the object of the research. Data in this research was collected through indepth interviews, observations, and documentation.
Subjects in this research are the Head and Staff of Universitas Tarumanagara Office of Public Relations, and a media journalist that often corresponds with Universitas Tarumanagara. The object of this research is media relations activities that are conducted in order to form the image of Universitas Tarumanagara. Data processing and analysis were conducted with the coding method. Triangulation was used as a data verification method.

\section{FINDINGS AND DISCUSSIONS}

\subsection{Universitas Tarumanagara Office of Public Relations Purposes: Manage Communications, Increase Publications, and Maintain Reputations}

Frank Jefkins [5] further explained that the purpose of public relations is to build a favorable image and decrease or even remove the unfavorable image of an institution. Generally, the purpose of public relations in universities are the same, whether in private or public universities. The main purpose is to assist management in managing the university, especially in communicating policies, achievements, academic and non-academic activities, the results of research and community service engagement, and others to the external public and internal public.

Universitas Tarumanagara Office of Public Relations was established to support the management of Universitas Tarumanagara in public communication aspect and to maintain reputations. The establishment of Universitas Tarumanagara Office of Public Relations resulted in better internal communications management, an increase of publications in media that made Universitas Tarumanagara more well-known, and events become more organised.

\subsection{Universitas Tarumanagara Office of Public Relations Functions: The Implementations of Private University Public Relations in Universitas Tarumanagara}

The main function of public relations is to maintain external and internal relationships. Public relations are demanded to be professional at all times as they intersect with many people throughout the day [5].

External communications are conducted by building communications with stakeholders such as government institutions, other universities, media, and others. Meanwhile, internal communications are conducted not only to students, alumni, and parents but also to the management in the form of inputs regarding policies.

Activities performed by the Universitas Tarumanagara Office of Public Relations are the same within other universities. The differences are the managements that are adjusted accordingly to the publics of Universitas Tarumanagara, and the active utilization of intern students. 


\subsection{University Public Relations Functions: Universitas Tarumanagara Office of Public Relations in Event Management and Decision Making}

British Institute of Public Relations (IPR) [6] stated that public relations is a planned and continous effort to maintain good will between an organisation and its publics. This effort is done to create mutual understandings between an organisation and its publics. Lesly [6] further explained that one of public relations' operational aspects is to build good image of an institution.

Lumbard and Stewart [7] stated that school public relations is a two-way process of communication between a school and its publics, to support school developments. This definition can be implemented in universities, having the same function as schools, namely the educational function. Nasution [7] stated that there are two functions that a university public relations need to execute, namely Constructive Function and Corrective Function.

Constructive Function in terms of media relations has been properly executed. This includes inviting media for event coverage, conducting partnerships, media handling, and media gathering, and inviting media to attend various events. In terms of the external public, the constructive function is performed in building relationships with various institutions in various events.

Constructive Function in terms of external public has been carried out through building and maintaining relationships with various institutions. Various institutions stated here including government and non-government institutions. Relationships between Indonesian National Army (TNI), Indonesian National Police (Polri), Mayor's Office, District Office, local society, corporates, alumni, and others. The implementations of these relations are reflected in various events held by Universitas Tarumanagara, such as Dies Natalis event, religious events, "Universitas Tarumanagara Peduli" social act that was carried out in Covid-19 pandemic, and others.

Corrective Function is executed through inputs to the management regarding policies to develop Universitas Tarumanagara. Also, information regarding branding is informed to the internal public and external public. The corrective function is also carried out through clarification if there any inaccurate news emerges.

Universitas Tarumanagara Office of Public Relations is actively involved in event management and decision making. This shows that Universitas Tarumanagara is one of the private universities that able to utilize the public relations division in daily operations.

\subsection{Media Relations in Universitas Tarumanagara Office of Public Relations: Implementations in Various Events}

Nova [8] stated that media relations, also known as media relations, is a form of communication conducted by an institution's public relations. This relationship is performed to build a good relation and understanding in order to maximize publications. Makmur further explained that media relations is considered important in public relations programs as the result of this activity can be seen through publications in media [9]. Nonetheless, disagreements in negative news could result in trouble for the said institution [2].

Universitas Tarumanagara through Universitas Tarumanagara Office of Public Relations carries out media relations activities. Media relations is an activity that build relations with media. Media relations are conducted through several activities such as press conferences, press gatherings, partnerships in publications, and Universitas Tarumanagara advertisements in media.

According to the Universitas Tarumanagara Office of Public Relations internal data, until 3 December 2020, there is 183 news regarding Universitas Tarumanagara, which are spread in 47 media throughout 2020. This included an online news portal, radio, television, and newspaper. It can also be seen from this data that there is about 15 news regarding Universitas Tarumanagara that were published to the media every month.

From these statements, it can be concluded that the Universitas Tarumanagara Office of Public Relations often carries out media relations through various formal and informal activities such as gathering after an event. Media relations activities that have been conducted have resulted in many media publications regarding various events that have been carried out by Universitas Tarumanagara.

\subsection{Universitas Tarumanagara Office of Public Relations with Media: A Distinctive Relation Formed through Informal Relations}

Makmur [9] stated that public relations and media need each other. Public relations need media for publications, and media need public relations for news material. Although both of them hold a mutual relationship, each has a different goal. The goal of public relations is to maintain the institution's reputation, while media put forward news value, neglecting whether its value is positive or negative. This could cause miscommunication between public relations and media.

Media relations activities that have been carried out by Universitas Tarumanagara through Universitas Tarumanagara Office of Public Relations have generated various publications regarding Universitas Tarumanagara. Publications are also expected to build public trust in Universitas Tarumanagara through brand awareness and brand image. Universitas Tarumanagara also has close relationships with various media. These relationships are the result of not only formal but also informal media relations activities such as bonding and maintaining decent communications.

Universitas Tarumanagara is considered very well in building relationships with media. Universitas Tarumanagara has close relationships with various media, including big and well-known media in Indonesia, such as Kompas.com, Okezone, and SCTV. These special 
relationships are reflected through events such as Scientific Writing Training, media visit to Okezone office for a talkshow session, inviting SCTV Chief of Staff as a speaker in Universitas Tarumanagara, and others. In some cases, media personnels will contact Universitas Tarumanagara in advance to ask for press releases and publications regarding an event.

Universitas Tarumanagara also obtained an exclusive column in online news portal Kompas.com, namely "Untar untuk Indonesia", that accommodates lecturers of Universitas Tarumanagara in publishing their popular scientific writings. This column was open for public access in March 2020, and until December 2020, this column has been accessed by about 2.3 million readers.

Private universities are necessary to have more aggressive and massive publications compared to public universities. Until now, Indonesians assume public universities better and prioritize public universities as their main options. Publications in various media serve as existential evidence and information sources to private universities' achievement and serve as a platform to promote private universities. Achievements and accomplishments could be a consideration for future students in choosing universities. Starting a relationship with the media is not an easy thing to do. Especially to private universities that never or rarely carry out said activity. But, if one succeeds, media relations can be beneficial towards the development of the private university. Media relations in the early stage does not have to be with big and popular media, but can be started with small media or local and regional media in the proximity of the private university.

\subsection{Media Relations Purpose: Publications for Universities}

In a higher education context, media relations can be a platform for publishing a university's achievements and outcomes. Through media, scientific papers can be published and popularised, so the public could be aware of this.

Media relations that have been carried out by Universitas Tarumanagara is aimed to publish achievements and outcomes of Universitas Tarumanagara to the public. The more outcomes generated, the more the public become aware to Universitas Tarumanagara. This could create positive results for the sustainability of Universitas Tarumanagara. The purpose of executing media relations in other universities is reflected in the activities of media relations carried out by Universitas Tarumanagara.

\subsection{Private University's Image: Forming Image through Quality}

Frank Jefkins [10] stated that image is real overviews, sensations, or impressions toward various policies of an institution. Image is the perception of the public that is formed through various experiences of an institution.

Private universities generally do not have the same resources and support owned by public universities.
Moreover, Indonesians trust and favor public universities more as their primary choice. This makes private universities need to work extra hard on building their image. Negative news of a public university will not be significant to the sustainability of said public university. However, this is not relevant to private universities. A private university's negative news could affect said private university's reputations, reducing public trusts in said private university. Therefore, private universities need to consider their image more. Several factors need to be considered in building a private university image. These factors include the qualities of a private university, such as accreditation, alumni and lecturers' quality, facilities, and many more. Also, a private university needs to concentrate more on its reputation as reputations reflect the quality of a private university.

\subsection{Types of Images: Positive News Build Expected Image}

Frank Jefkins [11] stated that there are several types of images, such as the mirror image, the current image, the wish image, and the multiple images.

Universitas Tarumanagara's image in society is regarded as good. The expected image of Universitas Tarumanagara is a university that carries out the value of Integrity, Professionalism, and Entrepreneurship (IPE), and inclusivity. These values are assigned as Universitas Tarumanagara's branding that is consistently communicated through various publications in media.

According to the observation carried out by monitoring through Google search engine, news regarding Universitas Tarumanagara is positive throughout 2020. In the majority, the news published is about the implementations of "Merdeka Belajar-Kampus Merdeka", a policy set by the Ministry of Education and Culture of the Republic of Indonesia, in Universitas Tarumanagara. Other news published is about celebration events, student's and lecturer's achievements, accomplishments, and many more. Currently, the image of Universitas Tarumanagara in the public is as expected. This means the mirror image, the wish image, and the current image owned by Universitas Tarumanagara are in sync. Therefore, it can be said that the Universitas Tarumanagara has succeeded in using media relations as a method to build its image.

\subsection{Building the Image of Private Universities: Media Relations Has a Role in Forming the Image of Universitas Tarumanagara}

Savila \& Utami (2020) stated that numerous activities of an institution can form a positive image in society. The institution is not limited to corporates, but also universities. Media relations has a role in the forming of the image of Universitas Tarumanagara. Good relationships with media have helped Universitas Tarumanagara in building its expected image [12].

Universitas Tarumanagara Office of Public Relations maintained its relationships with media by inviting media to events, whether as guests or press, carrying out media 
gatherings, visiting media offices, and inviting media personnel as speakers in events held by Universitas Tarumanagara.

Media relations can serve as one of the answers needed by private universities in building their image. Good media relations could increase publications regarding a private university in various media. Therefore, the expected image of a private university could be formed. Media relations can be implemented as the positive role of media management in private universities. Management of media in a private university is needed to manage good relationships with media. Having good relationships with media could support the forming of positive image. Other than that, private universities need to initiate good relationships with media to obtain platforms for publications, promotions, advertisements and to form their image in society.

\section{CONCLUSIONS}

Universitas Tarumanagara Office of Public Relations is aimed to manage communications, increase publications, and maintain the reputations of Universitas Tarumanagara, similar to other universities' public relations divisions.

Media relations that has been carried out by Universitas Tarumanagara has a role in forming the image of Universitas Tarumanagara through various positive news. Positive news in media could be formed through the Universitas Tarumanagara Office of Public Relations's success in establishing relationships with various media. The established relationships are not limited to formal activities such as news coverage, but also informal activities such as bonding and gathering with media personnel after events, or by performing activities such as media gathering and inviting media personnel as speakers in events. Besides maintaining relationships, other activities such as sending press releases consistently, inviting media to events, media gatherings, and many more also supported the emergence of positive news regarding Universitas Tarumanagara.

Positive news are the evidences of Universitas Tarumanagara's existence and achievements. Through positive news, the public could be aware of the achievements and quailities owned by Universitas Tarumanagara. Besides, the expected image of Universitas Tarumanagara are reflected in that positive news. This will increase the reputations and public trust in Universitas Tarumanagara, which then will have a role in Universitas Tarumanagara sustainability.

\section{ACKNOWLEDGMENT}

\section{Faculty of Communication, Universitas} Tarumanagara supported this work. The author would like to appreciate everyone who has helped in the planning, writing, and finishing of this research. The author also would like to give high appreciation to all informants of this research, namely Head of Universitas Tarumanagara Office of Public Relations Dra. Paula T. Anggarina, M.M., Staff of Universitas Tarumanagara Office of Public Relations Jessica Stefanus, S.I.Kom., and Kompas.com journalist Yohanes Enggar Susilo.

\section{REFERENCES}

[1] S Setyanto, Y., \& Anggarina, P. T. Humas pada perguruan tinggi (hubungan dengan media pada institusi pendidikan). Konferensi ASPIKOM Surabaya, 2015.

[2] Susanto, E. H. Media relations dan transparansi informasi (tinjauan terhadap kesiapan badan publik dalam pemberlakuan uu keterbukaan informasi publik). In F. Hamid \& H. Budianto, Eds, Ilmu Komunikasi Sekarang dan Tantangan Masa Depan, 1st ed., Vol. 1, Issue 1, pp. 331-351, 2011. Kencana Prenada Media Group.

[3] Anggito, A., \& Setiawan, J. Metodologi Penelitian Kualitatif. Sukabumi, CV Jejak, 2018.

[4] Fitrah, M. \& Luthfiyah. Metodologi penelitian: penelitian kualitatif, tindakan kelas \& studi kasus. Sukabumi, CV Jejak, 2018.

[5] Aziz, M. H. Strategi komunikasi humas polda jatim dalam menangani pemberitaan hoax di media sosial. Universitas Diponegoro, 2020. http://eprints.undip.ac. id/80845/

[6] Triyono, A. Strategi media relations perguruan tinggi di surakarta (studi di univeritas muhammadiyah surakarta dan universitas sebelas maret). KomuniTi, 5 (1), 1-9, 2013.

[7] Setyanto, Y., Anggarina, P. T., \& Valentina, A. Branding yang dilakukan humas pada perguruan tinggi swasta. Jurnal Muara Ilmu Sosial, Humaniora, Dan Seni, 1(1), 171, 2017. https://doi.org/10.24912/jmishumsen. v1i1.347

[8] Maria, S. Aktivitas media relations dalam membentuk citra positif rumah sakit syafira kota pekanbaru, 2013.

[9] Makmur, R. Media relations di balik layar: praktik, tips, dan teori. Jakarta, Kompas Gramedia, 2019.

[10] Seniwati, Harmin, S., \& Amin, H. Peran public relation dan media relation dalam membangun citra 
positif hotel grand clarion kendari. Jurnal Ilmu Komunikasi UHO, 1(2), 2016.

[11] Dewi, N. E. P., \& Novita. Pembentukan citra perpustakaan oleh teks media massa di kotamadya surakarta studi kasus: pembentukan citra perpustakaan oleh teks media massa solopos periode bulan oktober 2009 sampai dengan bulan oktober 2010. Universitas Diponegoro, 2013. http://eprints.undip.ac.id/40983/

[12] Savila, D. M., \& Utami, L. S. S. Strategi corporate social responsibility dalam pembentukan citra perusahaan (Studi pada kegiatan CSR di PT. Wijaya Karya). Prologia, 4(2), 288, 2020. https://doi.org/10. 24912/pr.v4i2. 6511 